\title{
自由視点テレビのためのマルチカメラの画像変換
}

\section{Transformation of Multi-camera Images for Free Viewpoint Television}

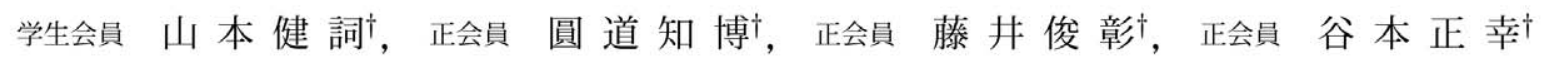

Kenji Yamamoto ${ }^{\dagger}$, Tomohiro Endo ${ }^{\dagger}$, Toshiaki Fujii ${ }^{\dagger}$ and Masayuki Tanimoto ${ }^{\dagger}$

\begin{abstract}
This paper introduces a preprocessing method for Free Viewpoint Television (FTV). In every multi-camera system, it is difficult to precisely align cameras in the desired place. For FTV, this misalignment reduces the efficiency of image compression and the quality of interpolated images. We propose a preprocessing method that transforms the captured multi-camera images by using projective transformation matrices to compensate for this misalignment. This transformation is able to improve them because the multi-camera images become more correlative. Furthermore, we introduce a method for automatically finding the projective transformation matrices using the epipolar geometry. Experimental results show that PSNR gains of up to $3.0 \mathrm{~dB}$ in comparison with compressions without any processing, when MPEG-2 is used under conditions ranging from 1.6 to $3.0 \mathrm{Mbps}$. The quality of the interpolated images is also apparently improved.
\end{abstract}

キーワード : 自由視点テレビ, マルチカメラ, 身影変換, エピポーラ幾何，画像圧縮，画像補間

\section{1. まえ がき}

実画像を利用して新たな画像を合成する Image Based Rendering(IBR) の研究が盛んに研究されており ${ }^{1) \sim 4)}$, 最 近では, それらの一つである複数のカメラを用いた自由視 点テレビ (図 1) ${ }^{5)}$ が注目されている.これは, ユーザの 見たい視点にあわせて3次元空間を自由に表示できるもの で，次世代のテレビ放送はもとより，セキュリティや環境 モニタ等の様々な分野への応用が期待されている ${ }^{6)}$. 自由 視点テレビを実現するために, 画像の圧縮技術 ${ }^{7) ~ 11) ~ や, ~ カ ~}$ メラの無い位置での画像を仮想的に作り出す補間技術 ${ }^{12) 13)}$ が今までに研究されてきた.

単一カメラの動画像の圧縮技術においては，画像の空間 方向执よ゙時間方向の冗長性を取り除くことで圧縮効果を 向上している ${ }^{14) 15)}$. マルチカメラの場合, これらに加えて カメラ間の画像の圥長性も取り除くことで, 高い圧縮率を 得ようとしている. そのため, カメラ間の画像に高い相関 性を持たせるほど, 高い圧縮効果が期待できる. 一方, 補 間技術においては, カメラが規則正しく配置されているこ とを前提に, 幾何学的な特性などから仮想的な画像を作成 している．そのため，カメラが規則正しく配置されている ほど, 高品質の補間画像が期待できる. 以上のことから, 圧

2005 年 2 月 23 日受付, 2005 年 10 月 20 日最終受付, 2005 年 12 月 6 日 採録

†名古屋大学 大学院 工学研究科

（广 454-8603 名古屋市千種区不老町, TEL 052-789-3163)

$\dagger$ Graduate School of Engineering, Nagoya University

(Fro-cho, Chikusa-ku, Nagoya, 464-8603, Japan)

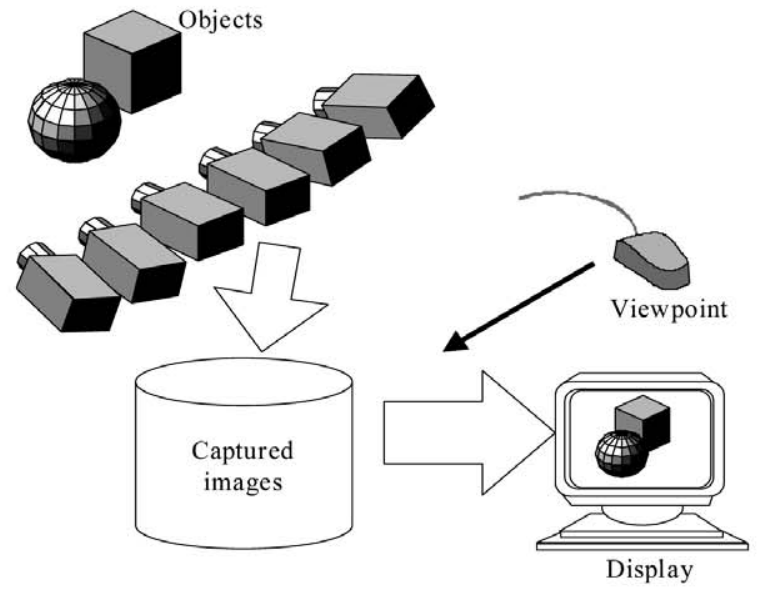

図 1 自由視点テレビ Free Viewpoint Television.

縮技術と補間技術の両方とも，カメラが規則正しく配置さ れているほど効果が期待できると言える.

実際の配置を考えてみると, 極めて正確に配置しようと しても, その通りに光学中心や画像面の位置, 姿勢などを 配置するのは困難である. そのため, 各カメラの撮影画像 を並べると, 並進, 回転などといったばらつきが目立つ. 本 論文では, 設計通りにカメラを配置しきれないことに起因 する, これらのばらつきを画像処理で補正することで, 画 像間の相関性を高め, 自由視点テレビの技術課題である圧 縮技術拉よび補間技術の性能を向上することを目的とする.

ここで補正するばらつきは, 補正による画素の移動量が, 画像サイズの $5 \%$ 程度未満になる大きさを考えている．こ 


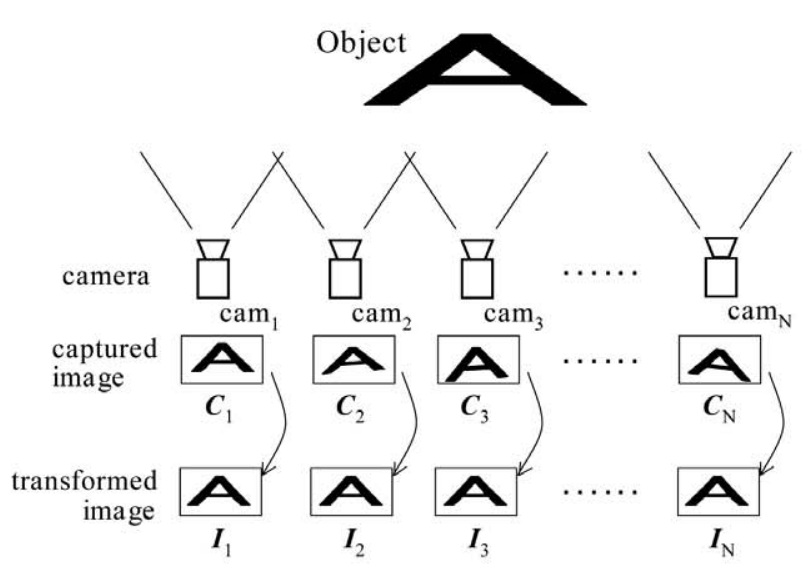

図 2 マルチカメラ画像変換

Transformation of multi-camera images.

れは, ばらつきが大きくなるにつれて, 補間画像の画角が 小さくなってしまうため, 極端なばらつきは自由視点テレ ビにとって望ましくないからである. $5 \%$ 程度以上のばらつ きはカメラの実際の配置で対処し，それ以下のばらつきを 画像処理で補正することを考える.

マルチカメラの画像変換は, 11 個のカメラパラメータ を求めてから行う方法が考えられる ${ }^{16) 17)}$. しかしながら, キャリブレーションパターンを撮影してない場合や, 一部の カメラだけは撮影できていない場合のように, カメラパラ メータを正確に求めることが困難なときもある. 従来, こ のような場合は, 試行錯誤を繰り返しながら手動で射影変 換行列を求める以外に手段はなかった. そこで, キャリブ レーションパターンを用いずに, 射影変換行列を自動で求 め, この行列で射影変換する手法を検討する. 射影変換行 列の算出に際しては, 設計上望んでいた画像に近い画像が 得られるように工夫した. キャリブレーションパターンを 用いて正確なカメラパラメータが求まる場合には, カメラ パラメータによる手法が, そうでない場合には, 本論文で 検討する手法が有効と言える.

本論文の構成は以下の通りである. まず2 章で撮影画像 を射影変換するマルチカメラ画像変換を提案する. 3 章で は, 自由視点テレビで多用されている直線状のカメラ配置 において, エピポーラ幾何を考慮することで射影変換行列 を自動で算出できる手法を示す４ 4 章で実験とその結果を 示し, 最後に 5 章で結論を述べる.

\section{2. 提案するマルチカメラ画像変換の概要}

静止画または動画を圧縮する場合, 通常は撮影した画像 をそのまま圧縮する．これをマルチカメラに適用すると， 各カメラで撮影した画像をそのまま圧縮することになるが, カメラ間の配置䛊差が原因で必ずしも効果的とは言えない. つまり, 動画像圧縮の国際標準である MPEG の予測方式 には画面の並進があるのみで, 回転や拡大, キーストーン 歪みといった参照がなく, これらが撮影した画像にあると うまく予測できない. また, 双方向予測は動きべクトルを
線形補間して予測するため, 画面が全体的に並進されてい るとうまく双方向予測できない. よって, カメラが規則正 しく配置されていないと上述のような問題が発生してしま い, 圧縮効率が低下してしまうと言える.

一方で補間においても, カメラ間の配置䛊差があると, 補 間画像の品質が劣化してしまうと言える. 補間では, 補間 画像を作成するために, エピポーラ線上で対応点を探索す るのだが, 設計上のエピポーラ線上に対応点が存在しなく なってしまうからである.

以上の点を踏まえて, 本論文では各カメラで撮影した画 像をカメラの画像面を移動して補正するマルチカメラ画像 変換を提案する（図 2)，具体的には，撮影した静止画ま たは動画をカメラ毎に異なる行列で射影変換して, その後 に圧縮や補間を行うことを考える. 射影変換を用いるため, 光学中心の位置を除く配置誤差から生ずる並進, 回転, 拡 大, キーストーン歪みという画像への影響を, 少ない計算 で取り除くことができるという特長が, この手法にはある. なお, 射影変換行列は時不変とするが, カメラとカメラの 間の位置関係を変化させた場合には変化させることとする.

一般的に射影変換の式は式 (1) 式 (3) で表現できる.

$$
\begin{array}{r}
\left(\begin{array}{c}
v_{i}^{\prime} \\
v_{j}^{\prime} \\
s
\end{array}\right)=\boldsymbol{H}\left(\begin{array}{c}
u_{i} \\
u_{j} \\
1
\end{array}\right) \\
\boldsymbol{H}=\left(\begin{array}{ccc}
h_{11} & h_{12} & h_{13} \\
h_{21} & h_{22} & h_{23} \\
h_{31} & h_{32} & 1
\end{array}\right) \\
v_{i}=\frac{v_{i}^{\prime}}{s}, v_{j}=\frac{v_{j}^{\prime}}{s}
\end{array}
$$

ここで $\boldsymbol{H}$ は射影変換行列で, 点 $\boldsymbol{u}=\left(u_{i}, u_{j}\right)^{t}$ を点 $\boldsymbol{v}=$ $\left(v_{i}, v_{j}\right)^{t}$ に変換する. $h_{11}$ から $h_{32}$ が変換の特性を表す. こ の $\boldsymbol{H}$ を用いて, 本論文で用いる画像の射影変換 $\boldsymbol{f}$ を式(4) 式 (7) と定義する.

$$
\begin{array}{r}
\boldsymbol{I}=\boldsymbol{f}(\boldsymbol{C}) \\
\boldsymbol{I}\left(i^{\prime \prime}, j^{\prime \prime}\right)=\boldsymbol{C}(i, j) \\
\left(\begin{array}{c}
i^{\prime} \\
j^{\prime} \\
s
\end{array}\right)=\boldsymbol{H}\left(\begin{array}{c}
i \\
j \\
1
\end{array}\right) \\
i^{\prime \prime}=\frac{i^{\prime}}{s}, j^{\prime \prime}=\frac{j^{\prime}}{s}
\end{array}
$$

ここで $\boldsymbol{C}$ は変換前画像, $\boldsymbol{I}$ は変換後画像, $i, j$ はそれぞ れ画素の $\mathrm{x}$ 座標と $\mathrm{y}$ 座標を示す.

射影変換行列 $\boldsymbol{H}$ は, 基準にするカメラや変換を評価す る方法により何種類も考えられる. ここでは画像を効果的 に圧縮でき，かつ補間画像を高品質にすることが目的のた め，そのようにできる射影変換行列を用いることとする. 


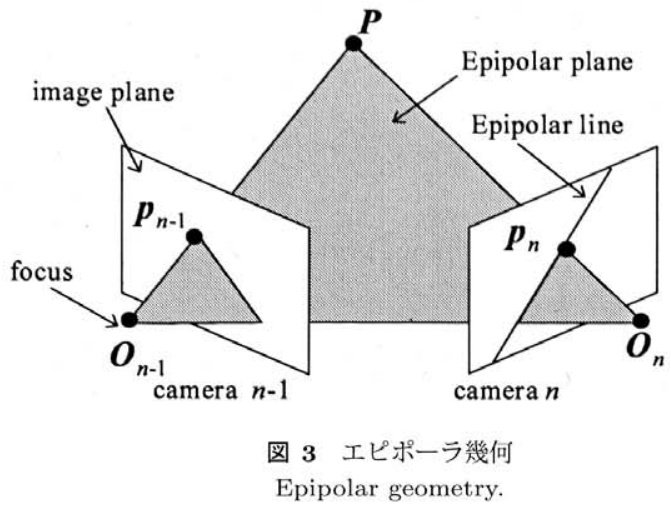

3. エピポーラ幾何を考慮した射影変換行列の算出

自由視点テレビでは, 通常, 複数のカメラを直線状また はアーク状, 円形状に等間隔に配置する ${ }^{5) 8}$. これらの配置 において, 良好な射影変換行列を自動で算出できる手法を 確立すれば有用と言える. 本章では, エピポーラ幾何を考慮 しながら良好な射影変換行列を探索する手法を示す．この 手法では, 直線状で等間隔, 同方向に向かせたカメラ配置, または近似的にそのようにみなせる場合において, MPEG にとって好ましい射影変換行列を自動で算出できる. 以下, 3.4 節にて計算手順を述べる. 3.1 節〜 3.3 節では 3.4 節の ための準備を示す.

3.1 エピポーラ幾何

本論文では, 2 台のカメラ間で成り立つエピポーラ幾

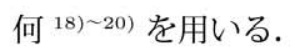

カメラ $n-1$ とカメラ $n$ があり, 光学中心をそれぞれ $\boldsymbol{O}_{n-1}$ と $\boldsymbol{O}_{n}, 3$ 次元空間の点 $\boldsymbol{P}$ に対応する画像面上の点をそれ ぞれ $\boldsymbol{p}_{n-1}$ と $\boldsymbol{p}_{n}$ とする. このとき図 $\mathbf{3}$ に示すように $\boldsymbol{O}_{n-1}$ と $\boldsymbol{O}_{n}, \boldsymbol{P}, \boldsymbol{p}_{n-1}, \boldsymbol{p}_{n}$ は幾何的な制約からすべて同一平 面上に存在することになる. また, $\boldsymbol{O}_{n-1}$ と $\boldsymbol{O}_{n}, \boldsymbol{p}_{n-1}$ が 既知で $\boldsymbol{P}$ と $\boldsymbol{p}_{n}$ が未知の場合, $\boldsymbol{p}_{n}$ は画像面上の一本の線 上に必ず存在することになる．このような興味深い幾何を エピポーラ幾何と呼ぶ. また, $p_{n}$ と $p_{n-1}$ を対応点, 同一 平面をエピポーラ平面, $p_{n}$ が存在する線のことをエピポー ラ線と言う.

\section{2 射影変換行列と变換後画像の評価法}

$\mathrm{N}$ 台のカメラで撮影した動画像のうち, 各カメラの同時 刻の画像を式 $(8)$ にて変換する.

$$
\boldsymbol{I}_{n}=\boldsymbol{f} n\left(\boldsymbol{C}_{n}\right)
$$

ここで, $n=1,2, \ldots, \mathrm{N}$ はカメラ番号, $\boldsymbol{f} n$ は射影変換行列 $\boldsymbol{H}_{n}$ での画像の射影変換, $\boldsymbol{C}_{n}$ は撮影画像, $\boldsymbol{I}_{n}$ は変換後 画像を表している.

どのような值の $\boldsymbol{H}_{n}$ に対しても $\boldsymbol{I}_{n}$ は計算できる. そこ で, $\boldsymbol{H}_{n}$ と $\boldsymbol{I}_{n}$ の評価として, $\boldsymbol{I}_{n}$ の品質を定量的に評価す ることとした. 評価の方法として条件 1 と条件 2 のみを考 え, 条件 1 からのずれ量と条件 2 からのずれ量との線形和

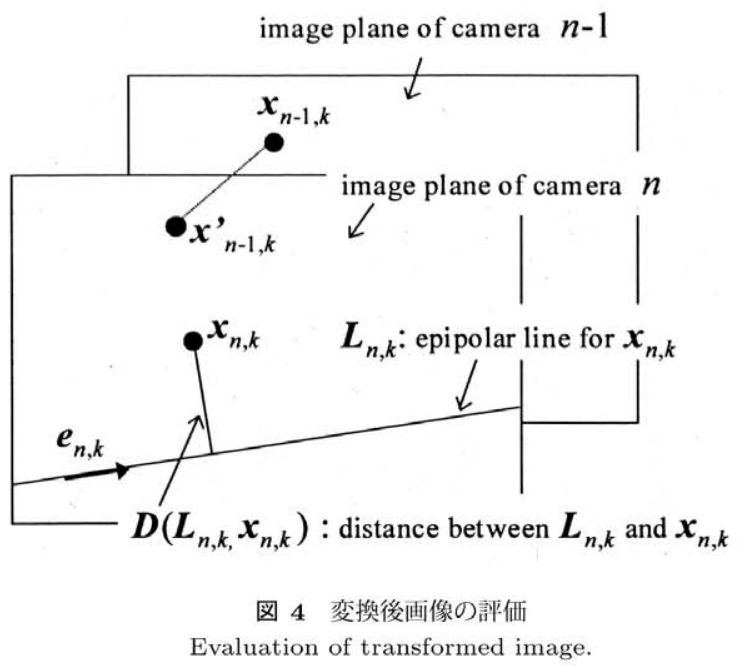

が小さい $\boldsymbol{H}_{n}, \boldsymbol{I}_{n}$ ほど, 優れた $\boldsymbol{H}_{n}, \boldsymbol{I}_{n}$ であるとした.

\section{条件 1 対応点がエピポーラ線上にある}

設計通りにカメラが配置されているならば，対応点 は設計上のエピポーラ線上にある．この線上に無いの は配置誤差が原因なので, 線上になるような変換をす ればよい. 変換後の画像 $\boldsymbol{I}_{n}$ において対応点が設計上の エピポーラ線に近いほど条件 1 が成立しているとする.

条件 2 対応点の平均距離はどの隣接カメラ間でも 等しい

本論文で対象としている直線状で等間隔, 同方向に 向かせたカメラ配置で, かつ単一平面上にすべての撮 影対象がある場合は, カメラ 1 とカメラ 2 の対応点間 の平均距離は, カメラ 2 とカメラ 3 のそれと幾何的な 理由から理論的に等しくなる. さらに, 背景の奥行き がほぼ一定で, 撮影対象がすべてのカメラで映ってい る場合などでも等しくなる．また，この関係はすべて の隣接カメラ間で成り立つ. そこで, 変換後の画像 $\boldsymbol{I}_{n}$ において, 対応点の平均距離がどの隣接カメラ間でも 等しいことを条件 2 とした.

条件 2 は, 先述の場合であれば有効な評価法になる. また, 単一平面付近に対象物が平均的に存在している 場合などでも近似的に成立するため，同様に有効にな る.これらの場合から外れた画像領域が多いほど有効 でなくなると言えるが, $\boldsymbol{H}_{n}$ の算出には全画像領域で の積算值を使うため, 条件から外れた領域の影響は積 算で打ち消される効果があることから，極端に有効で なくなることはない. さらには, この影響は $\boldsymbol{H}_{n}$ の算 出に対してであり, 条件から外れた画像領域を直接に 画質劣化させるようなわけではない.

以上に記した評価法を定式化すると式 (9)〜式 (15) になる.

$$
\begin{array}{r}
J_{n}=J_{v n}+\lambda J_{h n} \\
J_{v n}=\sum_{k=1}^{s}\left|D\left(\boldsymbol{L}_{n, k}, \boldsymbol{x}_{n, k}\right)\right|^{2}
\end{array}
$$



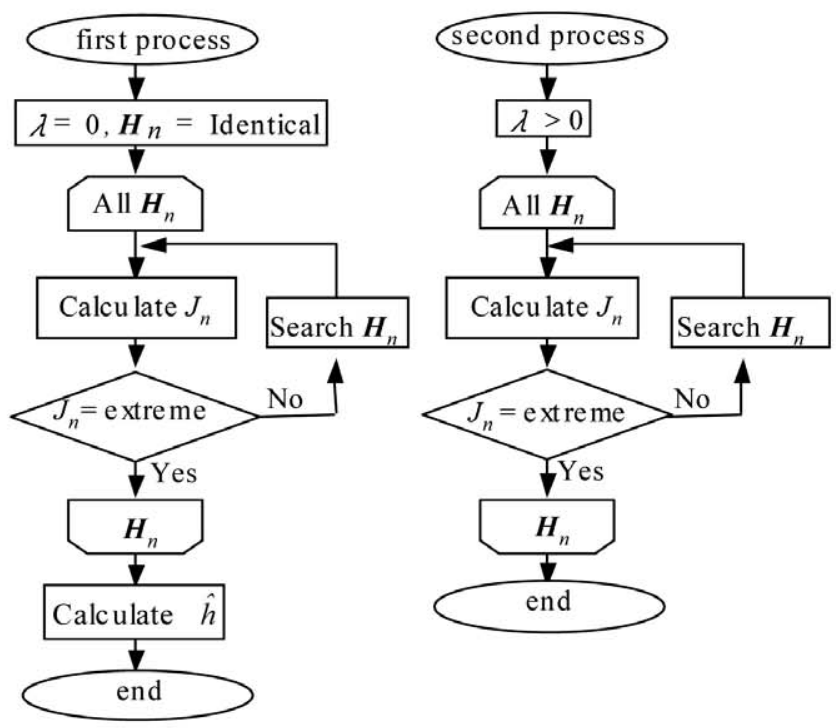

図 5 射影変換行列と変換後画像の算出手順

Calculation of the matrix and transformed image.

$$
\begin{array}{r}
J_{h n}=\left|\frac{\sum_{k=1}^{s} h_{n, k}}{s}-\hat{h}\right|^{2} \\
\boldsymbol{x}_{n, k}=\left(i_{n, k}, j_{n, k}\right) \\
h_{n, k}=\left(\boldsymbol{x}_{n, k}-\boldsymbol{x}_{n-1, k}\right) \cdot \boldsymbol{e}_{n, k} \\
\boldsymbol{x}_{n, k} \in \boldsymbol{S}_{n} \\
\hat{h}=\frac{\sum_{n=2}^{N} \sum_{k=1}^{s} h_{n, k}}{(N-1) s}
\end{array}
$$

ここで, 式 (10) と式(11) はそれぞれ条件 1, 条件 2を, 式 (9) はそれらを統合した評価関数を示している. 以下, 各 項の意味を述べる. $J_{n}$ は評価関数, $J_{v n}$ は条件 1 の評価関 数, $J_{h n}$ は条件 2 の評価関数, $\lambda(\geqq 0)$ は評価関数間の重み づけ定数, $\boldsymbol{x}_{n-1, k}$ はカメラ $n-1$ の画像面上の点, $\boldsymbol{x}_{n, k}$ は カメラ $n$ の画像面上の点で $\boldsymbol{x}_{n-1, k}$ の対応点, $\boldsymbol{L}_{n, k}$ は $\boldsymbol{x}_{n, k}$ に対する設計上のエピポーラ線, $D\left(\boldsymbol{L}_{n, k}, \boldsymbol{x}_{n, k}\right)$ は $\boldsymbol{L}_{n, k}$ と $\boldsymbol{x}_{n, k}$ との距離, $i, j$ はそれぞれ画素の $\mathrm{x}$ 座標と $\mathrm{y}$ 座標, $\hat{h}$ は $h_{n, k}$ の期待值である. $\boldsymbol{S}_{n}$ はカメラ $n$ の画像面上にある 対応点の集合で, $C_{1}$ と $C_{2}$ の間で求めた $S_{2}$ や, $C_{2}$ と $C_{3}$ の間で求めた $S_{3}$ など, すべての $S_{n}$ は 3 次元上では 異なる点の集合である. $s$ は $\boldsymbol{S}_{n}$ の要素数で画像サイズが $H \mathrm{x} W$ ピクセルとすると $s=H W / 256$, 演算子 (.) は内 積, $e_{n, k}$ はエピポーラ線と平行な単位ベクトルである（図 4). $\boldsymbol{x}_{n, k}$ に対するエピポーラ線は, $\boldsymbol{x}_{n-1, k}$ の位置とカメ ラ配置の設計值から求める. 評価関数 $J_{n}$ が小さいほど優 れていると判断する.

\section{3 射影変換行列 $H_{n}$ の精度}

本論文では, MPEG などで利用されているブロックマッ チングを用いて，16x16 のブロック毎に対応点を一つ求め る. 多くのアプリケーションでは, 誤った対応点がその後 の計算に大きく影響してしまうため, 慎重に対応点を決定 しているが，ここではブロックマッチングという簡単な手 法で対応点を検出することにした. 誤った対応点は $J_{v n}$ と

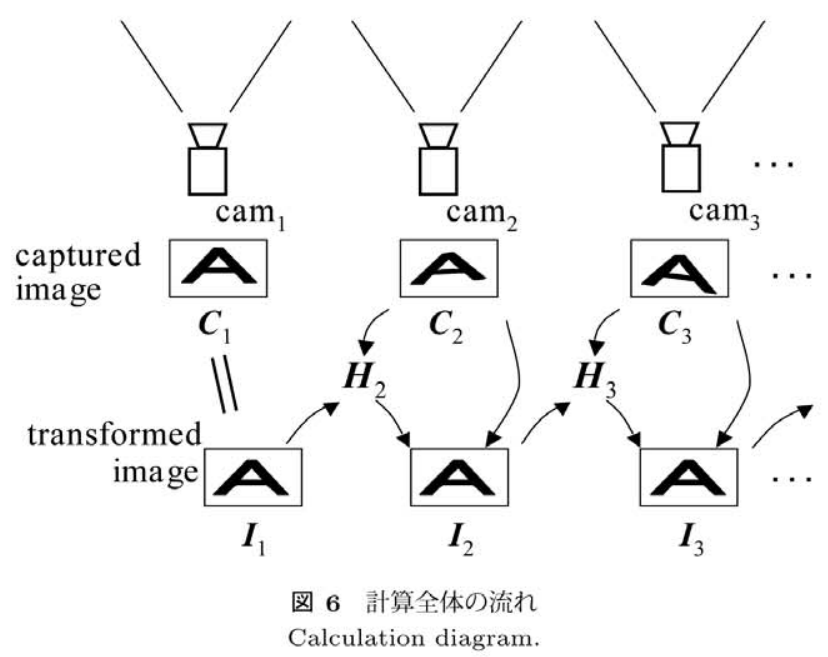

$J_{h n}$ に影響するが，これらの值は全対応点での計算の積算 值のため, $\boldsymbol{H}_{n}$ には大きくは影響しないと判断したからで ある*.

$\boldsymbol{H}_{n}$ が必要とする精度は, 撮影する対象構造によると定 性的に言える. 例えば, 精度が悪い射影変換でテクスチャ のほぼないような画像を変換した場合, MPEG の予測方式 では補償しきれないとしても, 予測画像が符号化する画像 に似ているために, 少ないビット量で圧縮してしまうこと が考えられる. 一方, テクスチャが複雑な画像を変換した 場合, 似た画像にならないために, 多くのビット量になる ことが考えられる. 補間においても同様で, 精度が悪い射 影変換でテクスチャのほぼないような画像を変換した場合 には，䛊った補間画像になるが，その輝度や色情報は本来 のものと似ているため, 似た補間画像になると考えられる. 一方, テクスチャが複雑な画像を変換した場合, その輝度 や色情報は似てないため, 低品質の補間画像になることが 考えられる. このように画像のテクスチャが複雑なほど精 度の高い $\boldsymbol{H}_{n}$ が必要になると言える.

\section{4 計算手順}

計算手順は二つのプロセスに分けることができる. 前半 は $h_{n, k}$ の期待值 $\hat{h}$ を確定するプロセスで, 後半は射影変換 行列 $\boldsymbol{H}_{n}$ と変換後画像 $\boldsymbol{I}_{n}$ を確定するプロセスである（図 5).

\section{プロセス 1 期待值の確定}

図 2 にあるように左から順にカメラ番号を付けたと する. 左側のカメラから順次, $\boldsymbol{H}_{n}$ と $\boldsymbol{I}_{n}$ を決定する.

まず始めにカメラ 1 では, 左側のカメラがないため に例外として扱い, $\boldsymbol{H}_{1}$ を単位行列とし， $\boldsymbol{I}_{1}$ を撮影画 像 $\boldsymbol{C}_{1}$ と同じとする. 次にカメラ 2 では, カメラ 1 の 変換後画像 $I_{1}$ とカメラ 2 の撮影画像 $C_{2}$ から射影変 換行列 $H_{2}$ を求める. その後に $C_{2}$ と $H_{2}$ とで変換後 画像 $\boldsymbol{I}_{2}$ を求める. カメラ 3 以降では, カメラ 2 と同

*例えば本論文で用いた $320 \times 240$ ピクセルの画像の場合, 300 組の対応 点を用いて射影変換行列を求めることになる. 仮に 10 組の䛊対応があっ たとしても, 全体の $3 \%$ 程度であるため, 積算值を用いる本手法では影 響がさいと考えられる。 


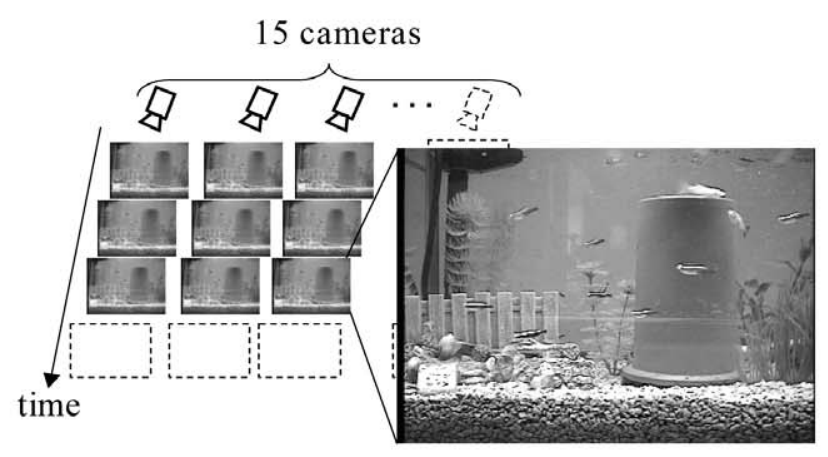

図 7 実験で用いた aquarium シーケンス Aquarium sequence.

様に最後のカメラまで求める（図 6)．ここでは左側 のカメラから順次求めたが, 右側からでも, 中央から 両側に向けて求めてもかまわない. 本論文の実験では 左側のカメラから順次求めた.

射影変換行列 $\boldsymbol{H}_{n}$ は最急降下法で算出する. 初期行 列を単位行列, 評価関数を $J_{n}$ として, $3 \times 3$ の成分の うち 3 行 3 列目以外の值を徐々に変えながら極值解を 探索させる. ただし，この時点では $\hat{h} か ゙$ 確定してない ため, 条件 2 の影響をなくす目的で $\lambda=0$ とする. 1 回に $H_{n}$ を変化させる量は $J_{n}$ の大きさに比例した量 とする. $\boldsymbol{H}_{n}$ を変化させる毎に $\boldsymbol{I}_{n-1}$ と $\boldsymbol{f} n\left(\boldsymbol{C}_{n}\right)$ から $\boldsymbol{S}_{n}$ と $J_{n}$ を求める.

繰り返し計算を行い， $J_{n}$ が極值解になったところで 計算を打ち切る. そのときの対応点間の距離 $h_{n, k}$ の平 均を期待值 $\hat{h}$ とする.

本プロセスは, 3.2 節の条件 1 を成立させるように $\boldsymbol{H}_{n}$ と $\boldsymbol{I}_{n}$ を計算することになる. そのため, 計算結 果で得られる $I_{n}$ は, 対応点がエピポーラ線上に並ん だ画像になる。

\section{プロセス 2 射影変換行列の確定}

プロセス 1 と同様に計算する. ただし $\hat{h}$ が確定して いるため $\lambda$ を正数（ $\lambda>0 ）$ とする. また, 最急降下法 での $\boldsymbol{H}_{n}$ の初期行列は，単位行列でも，計算時間を短 くするためにプロセス 1 の計算結果を用いてでもよい. 本論文の実験ではプロセス 1 の計算結果を用いた.

$J_{n}$ が極值解になったところでの $\boldsymbol{H}_{n}$ を最終的な射 影変換行列とする.

本プロセスは, 3.2 節の条件 1 と条件 2 の両方を成 立させるように $\boldsymbol{H}_{n}$ と $\boldsymbol{I}_{n}$ を計算することになる，そ のため, 計算結果で得られる $I_{n}$ は, 対応点がエピポー ラ線上に並び，かつ対応点の平均距離がどの隣接カメ ラ間でも等しい画像になる.

\section{4. 実 験}

画像の圧縮技術と補間技術において，撮影画像をそのま ま使った場合と, 提案手法のプロセス 1 終了時の画像（プ ロセス 1 画像) を使った場合, 提案手法で変換した画像 (変

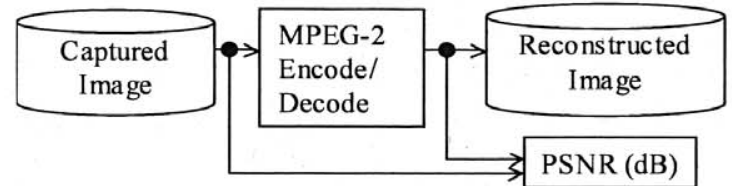

(a)

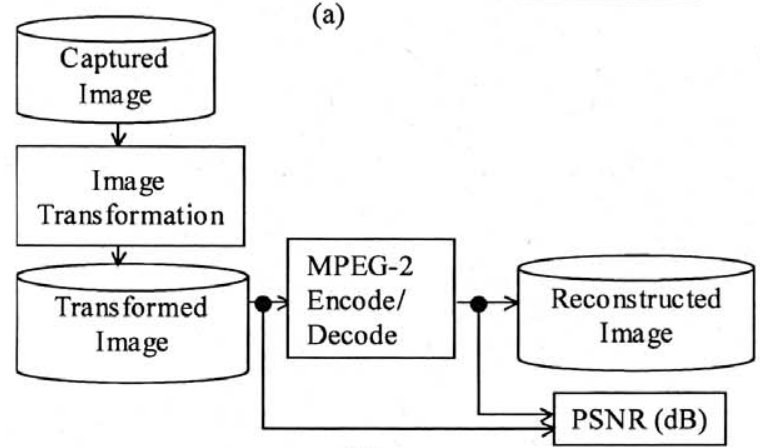

(b)

図 8 圧縮実験の方法

PSNR calculation between images.

(a) without preprocessing, (b) with preprocessing

換後画像）を使った場合，目視で試行錯䛊しながら得た最高 の変換画像 (目視変換画像) を使った場合を比較した. 両実 験とも aquarium シーケンス (図 7 $)^{21)}$ で行った. aquarium シーケンスの概要は以下の通りである.

・ 15 台の同じカメラ（株式会社東芝製 IK-SM43H, JK$\mathrm{L} 04 \mathrm{~S})$ で撮影, 焦点距離は $4 \mathrm{~mm}$, 受光面の大きさは $3.65 \times 2.74 \mathrm{~mm}$

・画像サイズは 320x240 ピクセル, 10fps で 80 秒 ・水槽とカメラの間隔はおよそ $350 \mathrm{~mm}, 3$ 間隔でカメラ を配置

aquarium シーケンスでは, カメラはアーク状に配置され ている. 直線状で等間隔，同方向に向かせたカメラ配置で はないが，近似的にはそのようにみなせると判断して本手 法を適用した.

実験には沉用 PC (Pentium4 3.4GHz, WindowsXP SP2）を用いた。圧縮実験と補間実験に先立ち，撮影画像 の輝度信号を浮動小数点演算で射影変換したところ, ニア レストネイバー補間での射影変換は $3.3 \mathrm{~ms} /$ frame, 線形補 間での射影変換は $8.8 \mathrm{~ms} /$ frame であった. 実験では, 線形 補間で射影変換を行った.

\section{1 圧縮実験の結果と考察}

マルチカメラの画像を圧縮する方法が多く研究されてい る. 本手法はそれら圧縮の前工程として, カメラ間の画像 の相関性を高めた画像を作ることを狙いとしている，そこ で, この相関性の変化のみを検証するために, 各カメラの 画像のうち同時刻の画像を並べて圧縮を行った. エンコー ダとして MPEG-2 TM55 ${ }^{22)}$ を用いて，輝度信号の PSNR （peak signal to noise ratio）にて効果を測定した（図 8).

$\lambda=46$ で行った各画像と圧縮率の関係を図 9 に示す. 変 換後画像での PSNR は，撮影画像をそのまま使った場合に 比べ，3.0dB 程度の向上していることがわかる．そのため, 目視変換画像に比較して $1.0 \mathrm{~dB}$ 程度劣るものの, 目的であ 


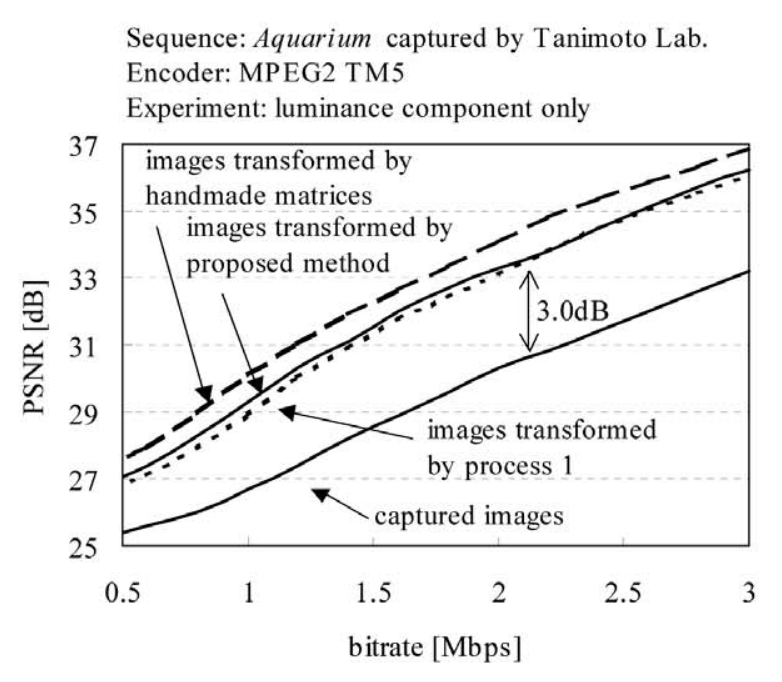

図 9 圧縮実験の結果 PSNR of reconstructed images.

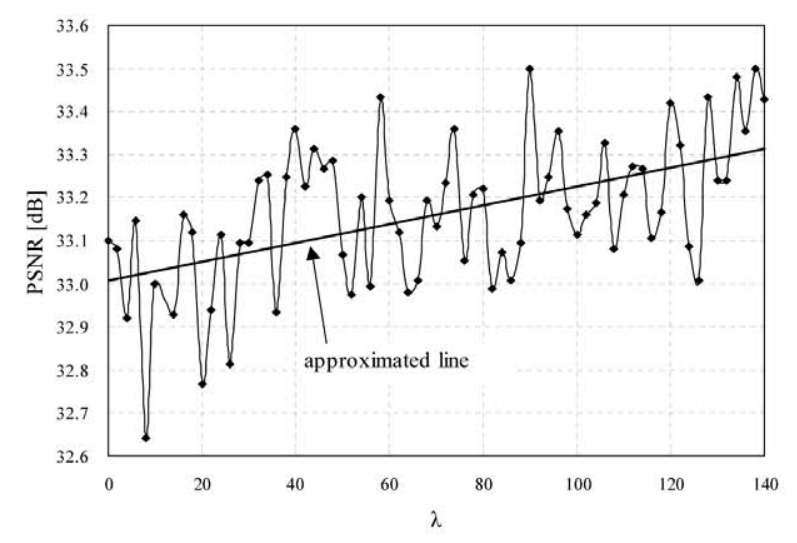

図 $10 \lambda$ と PSNR の関係 Relation between $\lambda$ and PSNR.

る圧縮の効率化がある程度達成できたと考えられる.

次に $2.0 \mathrm{Mbps}$ で行った $\lambda$ と PSNR の関係を図 10 に示 す. $\lambda$ により PSNR が最高で $0.9 \mathrm{~dB}$ 程度の幅で変化する のが分かる.これは， $J_{n}$ の解空間には極值（ローカルミニ マ）が多数存在しており, 解探索がそのいずれかに終着す るからだと考えられる.このように $\lambda$ により結果が若干変 化はするが, 図 9 でプロセス 1 画像と変換後画像との結果 がほぼ同じことから, プロセス 2 は, 圧縮に対して平均的 には影響が無いと考えられる.

\section{2 補間実験の結果と考察}

圧縮実験と同様に, 各カメラの画像のうち同時刻の画像 を用いて補間を行った. 補間には, 視差マップの連続性を 確保しながら, 補間画像を作成するドローゼらの手法 ${ }^{12)}$ を 用いた. 補間画像の評価には, 圧縮とは違い原画像がない ため主観評価を用いた，補間画像の例を図 11 に, 主観評 価の結果を表 1 に示す.

図 11 に掠いて，(a) は撮影画像で補間した画像，(b) は プロセス 1 画像で補間した画像, (c) は変換後画像で補間し
表 1 補間画像の主観評価結果

Subjective evaluation of interpolated images

\begin{tabular}{l|l}
\hline \hline & $\begin{array}{l}\text { average of evalua- } \\
\text { tion results }\end{array}$ \\
\hline (a) captured images & 1.6 \\
\hline (b) images transformed by process 1 & 2.5 \\
\hline (c) images transformed by proposed method & 2.9 \\
\hline (d) images transformed by handmade matrices & 3.0 \\
\hline
\end{tabular}

た画像, (d) は目視変換画像で補間した画像を示している. 顕著に差が出た画面中央の海草付近の結果を拡大して (e) , (f) , (g) および (h) に示した. 画面中央の海草, レンガの 上端, レンガの右上端付近にいる熱帯魚など多くの部分で, 変換後画像や目視変換画像を用いた補間が優っているとい える. ドローゼらの手法では, 同一ラインの中から対応点 を探して補間画像を作成するため, 同一ラインに対応点に 類似した点が無いと補間画像の品質が大きく劣化してしま う.レンガの上端がそれにあたり, 変換がない場合には大 きく劣化している.

また, (b) プロセス 1 画像で補間した画像 と (c) 変換後 画像で補間した画像を比較すると, 画面中央や右側の海草 が明らかに異なる. そのため, 補間技術ではプロセス 2 を経 ることで品質が向上すると言える. プロセス 1 がエピポー ラ線上に並べること, プロセス 2 がそれに加えて対応点の 平均距離を隣接カメラ間で等しくすることから, 変換後画 像の方が良くなると理論的に推測されることが, 実際に実 験で確認できた. プロセス 2 は圧縮では大きな影響がなかっ たが, 補間には大きな効果があるため, 採用すべきプロセ スであると言える.

表 1 は, 被験者 23 人を対象に行った主観評価結果であ る. 被験者は, 画像の研究に携わっていない者ばかりであ る. 被験者には, 並び順を入れ替えた図 $11(\mathrm{a}) \sim(\mathrm{d})$ を見せ て, 最も自然と感じる画像から順に $4,3,2,1$ 点と付け させた. 表 1 はこの平均点を記したものである. 推測され た通り, (d) 目視変換画像が最も評価が高く, 以下, (c) 変 換後画像，(b) プロセス 1 画像，(a) 撮影画像の順であった. 補間の研究では, 撮影治具として高精度のステージを用 いて, 単一のカメラで撮影した画像を対象にしている。 一 方, 自由視点テレビなどの一般的なマルチカメラでは, 高 精度の撮影治具を用いずに, 複数のカメラで撮影した画像 を対象にする. 後者のような場合においては, 補間の前に 提案手法を適用したほうが優れていると言える.

\section{5. むすび}

マルチカメラの撮影画像を並べると, 並進, 回転などと いったばらつきが目立つ. そこで, これらのばらつきを画 像処理で補正することで, 自由視点テレビの技術課題であ る圧縮技術と補間技術の性能を向上させる手法を提案した. また, 直線状で等間隔, 同方向に向かせたカメラ配置にお いて, 良好な射影変換行列を算出できる手法を示した. 提 


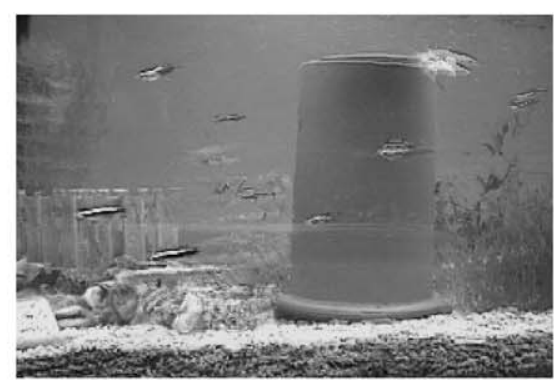

(a) captured images

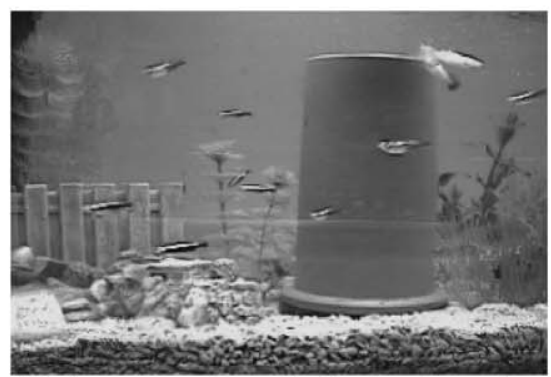

(d) images transformed by handmade matrices

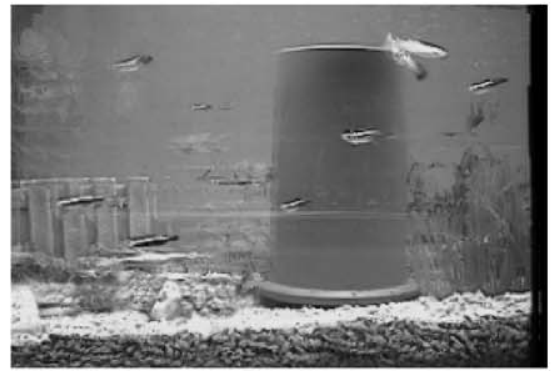

(b) images transformed by process 1

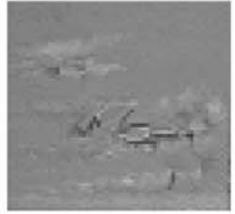

(e) waterweed in (a)

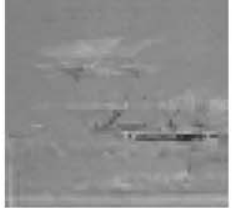

(f) waterweed in (b)

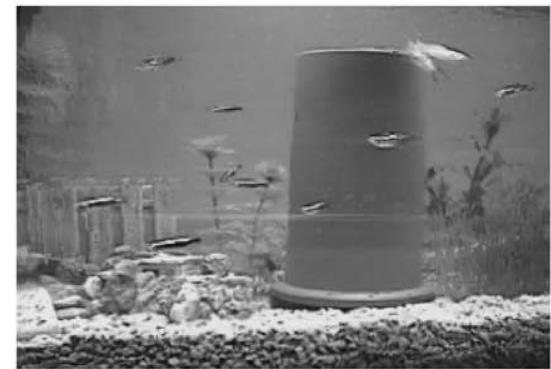

(c) images transformed by proposed method

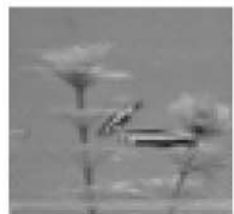

(g) waterweed in (c)

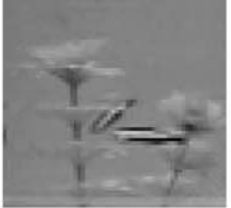

(h) waterweed in (d)

図 11 補間実験の結果

Interpolated images.

案手法には, 射影変換のため少ない計算で画像変換できる, 射影変換行列を自動で算出できるという特長がある. 実験 結果により，本手法が圧縮技術扔よび補間技術の両面で効 果あることが確認された。

本手法では, 光学中心の位置誤差は補償できないため,こ の位置誤差が大きいと, 圧縮効率と補間画像の品質の両方 に影響があると言える．また，対応点の平均距離はどの隣 接カメラ間でも等しいという条件を用いているが，この条 件が成立しないほど, 補間画像の品質に影響があると言え る. また，光学中心の位置䛊差は補償できないため，この 位置䛊差が大きいと同様に悪くなると言える. 今後は, こ れらの関係について定量化したいと考えている. また，直 線状と見なせないカメラ配置でも射影変換行列を算出でき る手法も検討する予定である.

\section{〔文献〕}

1）藤井俊彰, 原島博：“構造抽出に基づく三次元画像符号化”, 画像符号化 シンポジウム, pp.23-24 (Oct. 1994)

2）藤井俊彰, 金子正秀, 原島博：“光線群による 3 次元空間情報の表現と その応用”, テレビ誌, 50, 9, pp. 1312-1318 (Sep. 1996)

3) Marc Levoy, Pat Hanrahan : "Light Field Rendering", Proc. ACM SIGGRAPH96, pp. 31-42 (Aug. 1996)

4) Steven J. Gortler, Radek Grzeszczuk, Richard Szeliski, Michael F. Cohen : "The lumigraph", Proc. ACM SIGGRAPH96, pp. 43-54 (Aug. 1996)

5) Purim Na Bangchang, Toshiaki Fujii, Masayuki Tanimoto : "Experimental System of Free Viewpoint Television", Proc. SPIEIST \& Electron. Imaging, 5006, 66, pp. 554-563 (Jan. 2003)

6) Mehrdad Panahpour Tehrani, Toshiaki Fujii, Masayuki Tanimoto : "Optimization of Multiuser Camera Sensor Network for Arbitrary View Generation", IWAIT 2004, pp. 311-315 (Jan. 2004)

7) Marcus Magnor, Bernd Girod : "Data Compression for LightField Rendering", IEEE Trans. Circuits \& Syst. for Video Technology, 10, 3, pp. 338-343 (Apr. 2000)

8）山中康司, 藤井俊彰, 谷本正幸 : “自由視点テレビのための円形カメラ配 置における光線空間情報圧縮”, 2004 年映情学年次大, 3-1 (Aug. 2004)
9) Shinya Oka, Toshiaki Fujii, Masayuki Tanimoto: "Dynamic RaySpace Coding Using Inter-view Prediction", IWAIT 2005, pp.1924 (Jan. 2005)

10）秋山修, 齐藤英雄：“視点間の射影幾何的関係を利用した多視点動画像 のデータ压縮", 映情学誌, 59, 1, pp. 136-145 (Jan. 2005)

11) Prashant Ramanathan, Bernd Girod : "Random Access for Compressed Light Fields Using Multiple Representations", Proc. International Workshop on Multimedia Signal Processing (Sep. 2004)

12) Michael Droese, Toshiaki Fujii, Masayuki Tanimoto : "Ray-Space Interpolation based on Filtering in Disparity Domain", Proc. 3D Image Conference 2004 (June 2004)

13）高橋桂太, 苗村健 : "Light Field Rendering における合焦判定法の空 間解析”, 信学技報, 104, 493, pp. 57-62 (Dec. 2004)

14) ITU-T Recommendation H.264 : "Advanced Video Coding for Generic Audiovisual Services", (May 2003)

15) Thomas Wiegand, Gary J. Sullivan, Gisle Bjontegaard, Ajay Luthra : "Overview of the H.264 / AVCVideo Coding Standard", IEEE Trans. Circuits \& Syst. for Video Technology, 13, 7, pp. 560-576 (July 2003)

16) Zhengyou Zhang : "A Flexible New Technique for Camera Calibration", IEEE Trans. Pattern Anal. \& Mach. Intell., 22, 11, pp. 1330-1334 (Nov. 2000)

17) Yuuya Kojima, Toshiaki Fujii, Masayuki Tanimoto : "New Multiple Camera Calibration Method for a Large Number of Cameras", Proc. SPIE-IST \& Electron. Imaging, 5665, 21, pp. 156-163 (Jan. 2005)

18) Richard Hartley, Andrew Zisserman : "Multiple View Geometry in computer vision", Cambridge University Press, Cambridge (2000)

19）佐藤淳 : “コンピュータビジョンー視覚の幾何学一”, コロナ社 (1999)

20) Charles Loop, Zhengyou Zhang : "Computing rectifying homographies for stereo vision", Proc. IEEE Conference on Computer Vision and Pattern Recognition, 1, pp. 125-131 (July 1999)

21) http://www.tanimoto.nuee.nagoya-u.ac.jp/

22) http://isotc.iso.ch/livelink/livelink/fetch/2000/2489/Ittf_Home /PubliclyAvailableStandards.htm 


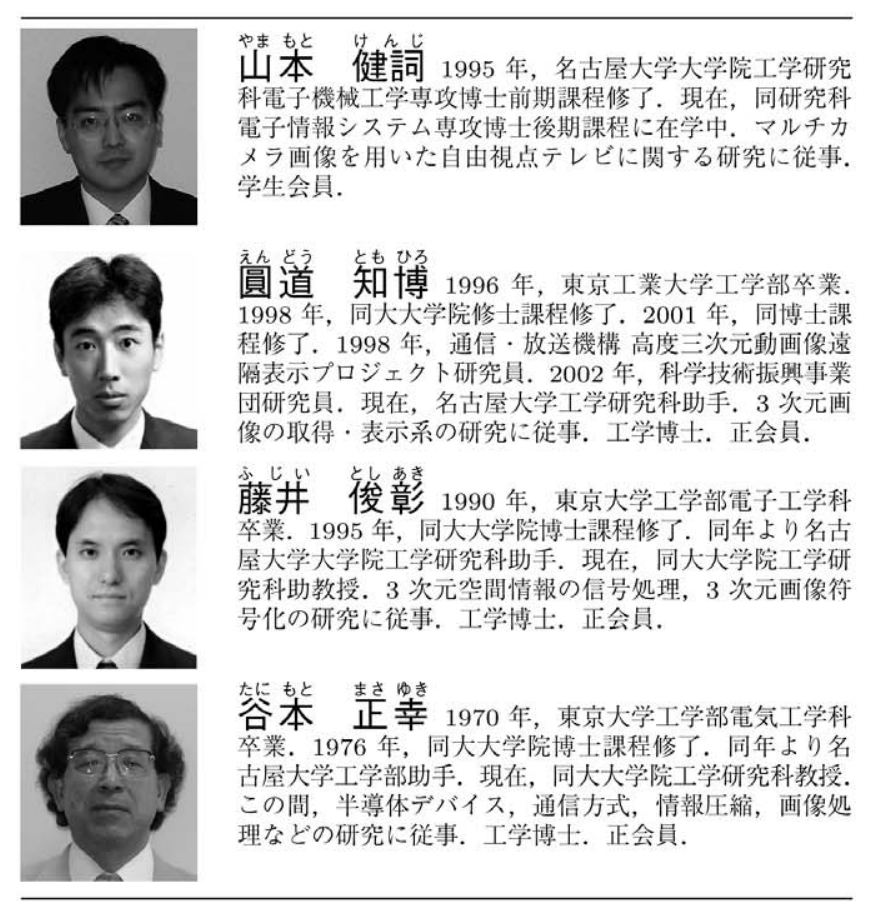

